\title{
MÁSCARA EM REDE NO AFROCARNAVAL
}

José Antonio Carneiro Leão (UFBA)

Estudo da máscara dos caboclos de lança do maracatu rural, entre a religiosidade e a carnavalização, e da configuração da linguagem visual desses brincantes do afrocarnaval. Na metodologia de educação pelo olhar, são apontados enredos entre a zona de visibilidade e invisibilidade no corpo-máscara, ao criar arte-movimento.

LINGUAGEM VISUAL NO AFROCARNAVAL; CORPOMÁSCARA; ARTE-MOVIMENTO.

LEÃO, José Antonio Carneiro. Máscara em rede no afrocarnaval. Textos escolhidos de cultura e arte populares, Rio de Janeiro, v.10, n.2, p. 47-64, nov. 2013. 


\section{THE MASK IN A NETWORK IN THE AFRICAN CARNAVAL}

José Antonio Carneiro Leão (UFBA)

This is a study of the mask of "caboclos de lança" in the rural maracatu, between religiosity and carnivalization. It analyses the configuration of the visual language of these afro-carnaval revelers. In a methodological approach of education through observation, plots are noted between visibility and invisibility zones in the body-mask when creating art movement.

THE VISUAL LANGUAGE OF AFROCARNAVAL; BODYMASK; ART-MOVEMENT.

LEÃO, José Antonio Carneiro. Máscara em rede no afrocarnaval. Textos escolhidos de cultura $e$ arte populares, Rio de Janeiro, v.10, n.2, p. 47-64, nov. 2013. 


\section{INTRODUÇÃO}

O maracatu rural surgiu por volta do final do século XIX a partir da mistura das culturas africanas, europeia e indígenas, pela fusão de ícones de vários folguedos populares, como pastoril, bumba meu boi, cavalo marinho, caboclinho, folia de reis, entre outros. Apesar do nome original, o termo maracatu passou a ser o mais utilizado para definir o encontro dos negros sob o nome de nação. Esse encontro era preparado para os orixás, quando entoavam músicas e realizavam cerimônia religiosa a fim de iniciar o ritual (ANDRADE, 1982). A expressão religiosa e carnavalizada do maracatu rural ajudou a compor enredos imagéticos na cultura pernambucana, contando atualmente com cerca de 92 grupos no estado, 21 deles em Nazaré da Mata.

O cortejo desse maracatu desfila num círculo, tendo ao centro o portabandeira, o rei, a rainha, a dama do paço com a boneca negra (a calunga), rodeado por outros personagens, mestre de toada, contramestre e caboclos de pena (arreiamar). Em volta desse primeiro círculo vêm os caboclos de lança, com compridas lanças de madeira (guiadas), que movimentam em diferentes direções. Eles brincam nos espaços públicos em meio à multidão e com suas divindades Exu nas encruzilhadas, junto com Ogum - abrem os caminhos, enquanto correm, saltam e dançam, com seu jogo de guiadas. Em plena região canavieira, os cortadores de cana trocam as enxadas, as roupas de trabalho e os chapéus de palha do dia a dia, pelas fitas coloridas das lanças dos caboclos e indumentárias que chegam a pesar 25 quilos.

Este estudo analisa a "arrumação" dos brincantes ${ }^{1}$ do maracatu rural em Pernambuco, suas máscaras de indivíduos incorporados ao local com suas culturas contadas, dançadas, em ação griô, ${ }^{2}$ que a cada geração carregam na memória o legado de tradição da história oral também inscrita em sua visualidade. Seres humanos que aprendem e ensinam a sabedoria de um povo, através de sua arte dançada e cantada durante todo o ano, muito reverenciada durante o afrocarnaval $^{3}$ nas zonas rurais e urbanas das cidades.

Sua máscara ou vestuário, chamada de "arrumação" é composta de manta ou gola bordada com lantejoulas e miçangas (o maior orgulho, mais belo trunfo do caboclo) que cobre o seu corpo, hoje quase se arrastando pelo chão. Ela é usada por cima das roupas e do surrão; camisa de mangas compridas e cores vivas; calção bufante sobre a calça; tênis e meias coloridas - talvez no passado usassem alpercatas ou andassem descalços; na cabeça usam lenço sobre o qual colocam chapéu de palha com armação em funil e coberto com tiras de papel de seda colorido, arranjadas como uma cabeleira de ráfia ou papel laminado. Hoje uma tia- 
ra pode chegar a ter entre 700 e 800 pedaços de fita. Toda essa arrumação é um produto de interpenetração cultural, com modernas atualizações decorrentes do padrão de beleza e visando informar que sua tribo é a mais bela e a mais rica nova forma de fazer guerra, que ainda mantém na ponta da lança ou guiada tinta vermelha que representa o sangue tirado de outro caboclo.

Ao categorizar o espírito humano com a noção de pessoa, a de "eu", Marcel Mauss usa o termo persona para caracterizar a "máscara" no sentido original da palavra, ou seja, per/sonare, a máscara pela qual ressoa a voz (do ator), que tem relação muito próxima com o personagem mudo do drama e da pantomina. A palavra não parece ser exatamente de origem latina, mas sim etrusca, civilização com tradição de máscaras de ancestrais. É fato que sua "categoria do espírito vacilou em alguns pontos, noutros lançou profundas raízes" (MAUSS, 2003, p. 383).

As máscaras levam os indivíduos a encarnar uma casca local e/ou seres totêmicos na identificação com determinados grupos, em que o corpo se relaciona em troca com o ambiente e o mundo espiritual. A máscara possui ampliação no corpo como uma pele ( $A w o$ ) que atrai o olhar gerando beleza, como o axé que demanda atenção. A ela se podem atribuir diferentes facetas como rotas, pistas, interpenetradas de cosmovisão passadas através da paródia pelos brincantes que a utilizam nos territórios e fronteiras de seu próprio corpo para comunicar-se com o mundo, mantendo e transformando seus costumes nas diásporas do tempo.

Os brincantes costumam assumir máscara que reveste todo o corpo que dança, estratégia utilizada até a contemporaneidade, presente em Pernambuco, Brasil, através da manifestação cultural conhecida como maracatu rural. Dessa manifestação, tomo como foco de estudo o personagem dos caboclos de lança, com sua dimensão lúdica na performatividade do afrocarnaval, em que a negociação da transição de suas crises (reconstituição identitária, do equilíbrio, da harmonia social) ainda passa pela recuperação de valores socioculturais que têm a ver com uma visão do mundo característica essencialmente das sociedades rurais, em especial as afrodescendentes, considerando seus ritos e mitos estabelecidos entre homem, meio ambiente e a dimensão metafísica do ser.

Difundido no país inteiro, o carnaval é marca da população foliã, autêntica festa do tempo, do futuro, das alternâncias e renovações que seguiu a rota dos salões, mas não perdeu a força da resistência brincante nas ruas, demonstrada em sua imposição em caráter nacional independentemente da vontade social e política. Assim como em diferentes países europeus e americanos, no Brasil, o povo passa da condição de liderado à de líder e torna o carnaval o maior espaço 
democrático, no qual reflete a oportunidade dos disfarces das máscaras e fantasias, liberando a criatividade e a irreverência. Para Bakhtin (2008, p. 10),

todas as formas e símbolos da linguagem carnavalesca estão impregnados do lirismo da alternância e da renovação, da consciência da alegre relatividade das verdades e autoridades no poder. Ela caracteriza-se, principalmente, pela lógica original das coisas "ao avesso", "ao contrário", das permutações constantes do alto e do baixo ('a roda'), da face e do traseiro, e pelas diversas formas de paródias, travestis, degradações, profanações, coroamentos e destronamentos bufões, a segunda vida, o segundo mundo da cultura popular constrói-se de certa forma como paródia da vida ordinária, como um 'mundo ao revés'. É preciso assinalar, contudo, que a paródia carnavalesca está muito distante da paródia moderna puramente negativa e formal; com efeito, mesmo negando, aquela ressuscita e renova ao mesmo tempo. A negação pura e simples é quase sempre alheia à cultura popular.

No brincante caboclo de lança o riso sério, sarcástico e burlador se confunde com sua performance visual-sonora por meio de seus chocalhos na altura dos rins (sua "bunda alegre"), escondidos sob as mantas que lhe cobrem o corpo. A sociedade aqui permite e revela sua verdadeira face, talvez ela mesma retire nesses dias de carnaval sua própria máscara, passando todos à condição de "cômico, jocoso, de riso ambivalente: alegre e cheio de alvoroço, mas ao mesmo tempo burlador e sarcástico, nega e afirma, amortalha e ressuscita simultaneamente" (BAKHTIN, 2008, p. 10).

Em pesquisas no Arquivo Público de Pernambuco foi possível identificar nas reportagens dos jornais locais de época que a máscara carnavalesca, predominante nos teatros e salões dos bailes de máscaras frequentados pela elite, foi ali, aos poucos, tomando fôlego, ganhando forças, até projetar-se e espalhar-se pelas ruas. Isso entre 1850 e 1852, quando as fantasias apresentavam as figuras mais cômicas e "ridículas" ou as mais elegantes.

Em Pernambuco, tanto na zona rural como na urbana, o costume de dançar pelas ruas em cortejos e o uso de máscaras durante os dias de carnaval eram próprios dos negros desde os tempos do Brasil colônia. A elite, contudo, interessada em fazer uso das máscaras durante essa festa, apropriou-se dessa antiga prática dos negros africanos no Brasil, sendo possível atribuir-lhe um novo significado, o de entrelugar social.

Ao reconverter-se em pós-ruralidade, a máscara deixa de ter conotação de costumes "selvagens" e passa a ter elementos significativos com base na burguesia europeia, esquecendo o passado colonial para transformar-se em sinal de civi- 
lidade, bom gosto e luxo, tanto para os brincantes como para as elites burguesas, que reconfiguram processos de emblematização da cultura também de cenário rural. Foi o que aconteceu com os caboclos de lança do maracatu rural, protagonizados por cortadores de cana-de-açúcar, com toda a sua arrumação.

Na área rural do norte da Zona da Mata pernambucana, no Nordeste brasileiro, os brincantes caboclos de lança que saem no carnaval trazem consigo povos indígenas e africanos que se juntaram em defesa de sua sobrevivência/persistência humana e cultural. Essa aproximação ganha em Pernambuco o sentimento de larga e ininterrupta teia de subúrbios na zona urbana. E inversamente, no campo, as aldeias e as freguesias tornam-se cada vez mais arredores de redes regionais de cidades médias, às quais suas relações culturais estão ligadas de diversas maneiras.

As relações culturais - desiguais e desniveladas - para Homi Bhabha (1998) requerem que vejamos os antagonismos do mundo global como "contiguidades" sociais e políticas. A globalização não é um processo de supressão das diferenças - segmentação, hierarquização -, mas, sim, de reprodução, reestruturação e sobredeterminação dessas mesmas diferenças, que se aproximam. É um processo de simultânea revelação/anulação de diferenças, diferenciação/homogeneização e democratização/hegemonização cultural, em que as coisas giram em torno de comprometimentos ancestres, recriados e adaptados às experiências contemporâneas que atendem a desejos individuais ou estão destinados a uma memória de grupo, de um eu social. O saber ancestral passa a ser um ponto de aglutinação e de difusão.

Os brincantes caboclos de lança interagem em seu cotidiano com o mundo que os circunda com suas antenas parabólicas, bem como nos dias de encontros (festas e feiras), de modo a transformá-lo e se transformam. Isso corresponde à melhoria do nível educativo como fator básico para aprimorar a produção cultural, ainda que os maiores bens culturais da região sejam imateriais e extremamente ligados à tradição oral, à tradição rural, à tradição dos não leitores, que não se fossilizou como algo folclórico, algo a ser só lembrado. Suas tradições renovadas funcionam como maior motivação na produção de novas loas, ${ }^{4}$ versos e elementos cênicos incorporados do mundo globalizado, com trânsito rural e urbano, para o estabelecimento de teias e cadeias de produção, bem como reprodução das maneiras de pensar a utilização de suas máscaras.

Muitas pessoas nunca tiveram oportunidade de experiências criadas pelo progresso tecnológico (navegar pela internet, andar de elevador, viajar de avião, etc.), e em suas casas pode talvez faltar muita coisa; não falta, porém, uma antena parabólica para se ligar ao mundo, dialogando com suas experiências de sabe- 
res rurais. Gente que se educa na tradição oral e que, no descanso e na lida de sua enxada, fabrica ideias, cria valores e planeja o seu dia, abrindo seu caminho e imprimindo sentimentos a sua memória, com suas indumentárias, imagens que incorporam novos artefatos que compõem o seu ambiente e a busca de estar com o outro no lugar de suas ancestralidades. Isso constitui as teias de significações entre o mundo atual e a ancestralidade no cotidiano desses brincantes, nas redes dos entrelugares subversivos do dentro e fora do corpo, do visível e invisível, do permanente e transitório.

As práticas educativas necessitam dar mais visibilidade ao corpo. A visão predominante é a de que o corpo mascarado deve responder a um conjunto de estímulos a ele direcionado. Corpo, porém, é criação e demanda cuidados estéticos, de respeito a individualidades e singularidades humanas.

Tanto o educador como o aprendiz se esquivam da percepção sobre seus corpos. Há toda uma tecnologia na utilização e exploração do corpo em ambientes de formação. Por tecnologia não se concebe apenas o conjunto de equipamentos de natureza externa ao ser humano e a seu corpo. Pensar já é uma tecnologia (SIMONDON, 1969). Ao longo do tempo, o objeto como ampliação da pele perde seu caráter artificial $^{5}$.

Os objetos no corpo dos caboclos de lança nos maracatus surgidos na época do Brasil colônia, ligados aos festejos católicos do ciclo natalino, possuíam os sujeitos que protagonizavam os africanos escravizados e seus descendentes brasileiros, que também cultuavam as formas africanizadas de religião, no caso de Pernambuco, a banto (OLIVEIRA, 2003), depois generalizada como jêge-nagô (BENJAMIN, 1989 e CARNEIRO, 2008), com alguns traços também da cultura indígena. Ao longo da história, os cortejos de maracatus passaram a ser realizados no carnaval, assumindo ainda mais o caráter de festejo, profano para o pensamento eurocêntrico, e sagrado para os brincantes folgazões, como também são conhecidos.

Diante desse contexto sucinto, como ocorre a linguagem visual da máscara no corpo desses brincantes do afrocarnaval? Aponto um caminho metodológico de enredos numa tensão entre a zona de visibilidade e de invisibilidade no corpo, com inspiração etnográfica na perspectiva de teias simbólicas (GEERTZ, 2008), no exercício da criação de pensamentos diferenciais em que a arte cria sensações, perceptos. Para tanto, a pesquisa inclui dois aspectos: visibilidade em zonas de contatos interculturais; e invisibilidade dos espaços de confluências em saberes de experiências ancestrais. 


\section{VISIBILIDADE EM ZONAS DE CONTATOS INTERCULTURAIS}

O setor agrário caracteriza-se pela monocultura da cana-de-açúcar como principal produto agrícola pernambucano. Mesmo com a perda de dinamismo da agroindústria açucareira, não têm sido oferecidos obstáculos à expansão de outras atividades na mesorregião, em particular o turismo na área rural da Zona da Mata. Atividade que vem ganhando visibilidade em função de seus mestres artistas, de linguagem ora falada ora silenciada, na linha de fuga e reterritorialização, em relação a um modelo único de expressão visual, equivalente a uma determinada etnia ou identidade. Sendo assim, a linguagem visual brincante tem sido pensada, tanto em contraposição à imitação que corresponde ao devir desejado para eles como em sua dinâmica de implicações culturais do processo de globalização.

$\mathrm{Na}$ crise do devir, o que era negado no terreiro e nas varandas das casas passou a ser admirado e desejado pela grande sociedade global. As "danças nativas", as "coisas de negros", os "costumes de caboclo", o afrocarnaval tornaram-se testemunhos do tempo, fontes da nação e não apenas motivo para poemas saudosos dos tempos de criança dos moradores das casas-grandes dos engenhos, agora vazias de seus donos e que na atualidade, em função da cultura do povo, voltam a ser ocupadas como grandes hotéis-fazenda por visitantes interessados na cultura rica dos mestres brincantes.

Merece ser enfocado o turismo étnico rural como atividade que vem sendo incrementada aos poucos, e que em Nazaré da Mata tem sido um foco de aglutinação da manifestação cultural do maracatu rural com seu encontro de maracatus na segunda-feira de carnaval. Encontro esse que consagrou esse município da Zona da Mata norte como a "Terra do Maracatu", sobretudo, por ser sede do mais antigo maracatu rural em atividade, o Maracatu Rural Cambinda Brasileira, fundado em 5 de janeiro de 1918. Como memória no corpo de brincantes do afrocarnaval, sua linguagem visual cultural tem sido considerada atividade econômica em potencial. Sendo assim, a cultura vai transitando em tempos diferentes e termina por marcar a história do lugar, mantendo e transformando ao mesmo tempo sua estrutura arquitetônica materializada através da arte, mas que leva a processos educativos - ainda que fora dos enredos conceituais da educação escolar - à sensibilidade de axé (força) guerreira das nações de maracatu, configuradas por sua rede de máscaras brincantes.

O maracatu rural ou de baque solto ${ }^{6}$ e em especial seus personagens caboclos de lança são os protagonistas que retratam o costume da terra no cotidiano de seus moradores como uma missão de luz no axé, que é o alimento primordial 
e princípio ativo desde os terreiros, que se renova e se reafirma em cada oferenda/cerimônia, consagração de seus participantes, seus transes, entre outros aspectos, de culto acolhido de suas religiosidades, seus rituais, como valor que sustentou tanto o indígena nativo quanto o migrante africano escravizado, fazendoos transcenderem à dor, à humilhação, à fome e até à morte (MENEZES, 2005).

No diálogo com as manifestações culturais, localizadas à margem em seu percurso histórico, na periferia, percebe-se uma tensão marcada pela indiferença de indivíduos que não conseguem enxergar, nos elementos no corpo de brincantes do afrocarnaval, seu universo de simbologias, de significados que ainda estão presentes na dinâmica cultural da sociedade contemporânea. Assim, mesmo numa sociedade que parece ser tão avançada tecnologicamente, faz-se necessário romper com a visão fragmentada sobre corpo e todas as suas relações de banalização que perpassam a indústria cultural inserida na maioria dos setores da sociedade.

O convívio cotidiano com a sociedade de imagens acaba nos anestesiando tanto para figuras visuais como sonoras, insensibilizando os sentidos e empobrecendo-lhes as significações. Sendo assim, por mais que se aperfeiçoem os dispositivos tecnológicos, mais nos alienamos da percepção, e o esquecimento se apodera da memória.

Em resposta ao perigo de desligamento de nossos sentidos, a memória surge como matéria-prima por excelência na arte, no cinema, na literatura, na dança. Ilusões e sonhos passam a fazer parte da memória individual e coletiva na metáfora de diálogo vivo no corpo desses caboclos de lança.

O espaço no contexto do maracatu representa cenário no qual reconstituir a trajetória de brincantes, que também são educadores, sua prática e seus fundamentos no espaço, suas articulações com outros grupos numa espécie de cartografia corporal histórica na tarefa de perseguir aproximações e afastamentos, descontinuidade e rupturas. Estas são perspectivas de construir diferentes opções de aprender com esses intelectuais da cidade, como vem sendo configurada no corpo sua educação, a partir de uma metodologia pelo olhar das máscaras. Os brincantes carnavalizados, que representam experimentação polifônica fora das condições habituais de vida, superando dualidades, são atores-autores que fazem história e, mesmo sendo esquecidos na memória de diferentes culturas, dialogam com uma complexidade de habilidades, signos, dinâmicas, em prática lúdica interativa de criatividade e relação social.

Os corpos brincantes se comunicam, e as culturas africanas se instauraram na memória subterrânea adormecida, e prosseguem em subversão no silêncio das imagens ainda não interpretadas (POLLAK, 1989). São embates que prevalece- 
ram à visão holística e dinâmica (Homo Simbolicus) nos discursos sobre o uso do corpo ou ao estudar vivências e padrões de comportamento que dialogam com o natural (biológico) e o cultural (socioeducativo).

Esse enfoque não permite que seja revelado desprezo pelas miudezas do dia a dia, pela invenção do cotidiano apontada por De Certeau (1994), graças às artes de fazer táticas de persistência cujos objetos e códigos alteram, reapropriando-se, a seu modo, do espaço e do uso, com seus personagens anônimos, seus corpos, sentimentos, crenças e aflições em que se descobre o sujeito coletivo da história. Desse modo, podem então ser compreendidos relações sociais, usos, comportamentos, práticas e costumes relevantes que possam reconstruir uma pequena comunidade ou grupo no tempo, considerando o corpo objeto e fonte de estudo.

Como objeto e fonte de estudo, falo na contemporaneidade de um corpo de ancestralidade africana no continente americano, sem possuir territórios ou fronteiras firmes e bem demarcadas, com incorporação subversiva de povos formados pela imbricação das relações originárias dos entrecruzamentos de indivíduos que dialogam com diferentes ancestralidades.

As reflexões sobre corpo e suas máscaras não passam apenas pela questão da etnia, mas pela diversidade e desigualdade entre os seres humanos (escravidão $x$ exclusão $x$ diferenças). Considero que esse não é um espaço moralmente neutro, até porque essas discussões possuem um percurso de vida da construção simbólica na adversidade, dada a grande dificuldade enfrentada pelos brincantes.

O contexto atual dá visibilidade às diferenças que passam pelas estratégias de persistência presentes no diálogo vivo africano dos brincantes caboclos de lança. A reflexão sobre o significado e as implicações de ser negro tem sido pautada por interseções, contradições e pontos de convergência. Alimentam esse debate dois fenômenos sociais históricos amplamente relacionados: a escravatura e as formas de preconceito e racismo que são seu legado. Uma das maiores consequências da escravatura é a enorme dívida social histórica para com a população que ganhou a liberdade, configurando o debate público e a agenda de políticas sociais que visam saldar essa dívida.

O debate de saldar dívidas também passa por dar visibilidade ao entendimento de ancestralidade no corpo que tem mediação identificada nos brincantes do afrocarnaval aqui estudado, fazendo um recorte do conceito etnicoancestral como construto social de categoria da enorme diversidade étnica do país, como um sopro que impulsiona a imagem da alma brasileira. De acordo com Baudrillard (1997, p. 90), “Por trás da orgia das imagens, alguma coisa se esconde. O 
mundo furtando-se por trás da profusão das imagens é o caso de outra forma de ilusão talvez, uma forma irônica". É o caso da ousadia e da aventura presente na espetacularidade desses brincantes.

Segundo Dias e Gambini (1999, p. 88), existirá uma alma brasileira em que despertem imagens e palavras até então ocultas? Para eles "criar alma é um aprendizado de como viver", armazenado no vivenciar uma cultura do inconsciente como matriz do consciente. Revelar o inconsciente, portanto, é ver e ouvir no campo as várias formas possíveis de brasilidade, em que a afro-americana se inclui, marcada culturalmente nas sensibilidades descolonizadas dos brincantes de cultura, caracterizada pelo impacto dos direitos civis e nas lutas negras pela descolonização das mentes dos povos da diáspora negra.

\section{INVISIBILIDADE DOS ESPAÇOS DE CONFLUÊNCIAS EM SABERES DE EXPERIÊNCIAS ANCESTRAIS}

Ao encontrar em Hall (2003) a fundamentação necessária a uma releitura dos "fragmentos da ideologia", percebo estreita relação com a cultura, o conhecimento, a história, e através deles, por assim dizer, o meio ambiente invade o sistema linguístico e semântico de origem sociocultural, que é mediado por signos. Daí a necessidade da interação e da comunicação mediacional entre as gerações e entre as pessoas, garantindo a memória e a transmissão do acervo do patrimônio cultural da sociedade.

No que se refere às questões sobre memória, a perspectiva foi o estudo da linguagem sob a perspectiva do corpo desses brincantes, tendo como ponto de partida a relação África/América que se dá na transdução dos discursos que ocorrem nas práticas sociais, entendendo-se como transdução a tradução dos discursos incorporados no sujeito transformado a partir dos percursos realizados por ele. A memória é construída de forma significativa para, em seguida, ser significativamente decodificada em metáforas. Nesse aspecto, Hall (2003, p. 390) aponta que

é esse conjunto de significados decodificados que 'tem um efeito', influência, entretém, instrui ou persuade, com consequências perceptivas, cognitivas, emocionais, ideológicas ou comportamentais muito complexas. (...) Essas metáforas concebem o social, o simbólico ou o cultural como se fossem costurados um ao outro, por correspondência rudimentar, de tal forma que, quando as hierarquias sociais são derrubadas, uma inversão dos valores e símbolos culturais tem que acontecer, mais cedo ou mais tarde. 
Nas manifestações do afrocarnaval, os brincantes carnavalizados afroamericanos brasileiros apresentam um universo de simbologias, de significados presentes na dinâmica cultural da sociedade, que, na concepção antropológica de Geertz (2008, p. 24), representa uma "teia de significados", inserida no mundo simbólico das metáforas,

Como sistemas entrelaçados de símbolos interpenetráveis (...) não é um poder, algo ao qual podem ser atribuídos casualmente os acontecimentos sociais, os comportamentos, as instituições ou os processos; ela é um contexto, algo dentro do qual eles podem ser descritos de forma inteligível, isto é, descritos com densidade (GEERTZ, 2008, p. 24).

Nos sistemas entrelaçados de símbolos também percebo que as metáforas estão ligadas às experiências corporais comuns, transmitindo não um movimento pronto, mas as conexões que levam ao movimento (LAKOFF; JOHNSON, 2002). Nesse sentido, foi preciso entender de que maneira as metáforas "encarnam" nos brincantes do afrocarnaval. Assim, a habilidade simbólica (forma de os brincantes corporificarem um conteúdo estético) é conquistada e organizada estabelecendo relações de semelhança e aproximações. Os enredos estabelecidos nessa relação são capazes de vínculos em contextos variados, se configurando numa passagem de níveis de menos para mais complexidade, numa mudança de combinações entre símbolos (PEIRCE, 2008). Através de expressões corporais carregadas de intersubjetividade pelos brincantes, foi possível observar durante o carnaval de 2011, nos caboclos de lança do Maracatu Rural Cambinda Brasileira, em Nazaré da Mata, seus papéis, seus lugares, seus procedimentos de relação e suas estratégias de ação.

Como linguagem de ação dramática, dançando esses brincantes ativam o axé com seus cordões em fileiras e filas de caboclos de lança formando um paredão de proteção para os demais personagens. Geralmente o maracatu é puxado por cinco caboclos de frente: um puxa o cordão do lado direito (que representa os eguns/orixás), outro puxa o cordão esquerdo (que representa os inquices/Jurema), outros dois caboclos - boca de trincheira - puxam um arreiamar de cada lado, e o caboclo mestre, que puxa todos os caboclos, dá o comando para as cortadas e as manobras com as guiadas, através de sinais aos puxadores de cordões. O caboclo mestre faz algum gesto discreto com a bengala (bastão) para o lado, ou roda, ou aponta, indicando, assim, o que fazer para puxar o maracatu. Às vezes ele para, e os quatro caboclos de frente puxam o maracatu e dominam todo o conjunto, apontando sua intenção de mistério, de irmandade, de militante, atento às transformações do mundo para ganhar visibilidade. Pude passar pela expe- 
riência como caboclo de lança nos dois lados dos cordões, e também na frente e atrás, percorrendo toda a sua circularidade.

A dupla superposição de presença em situações complexas mais visíveis (objetividade), sensíveis e perceptíveis pelo comparecimento efetivo de uma pessoa, de um objeto, numa imagem como a dos cordões serve de porta-voz de uma realidade que não pertence ao campo da apreensão direta, mas ao do invisível (subjetividade). A visão conceitual do plano invisível, dos sentimentos, passa a ser uma linguagem valorizada como escritura desvelada, intersubjetiva, de entrelinhas camufladas.

O campo da apreensão não direta (invisível) ocorre no nível simbólico pela incorporação de uma lei ou convenção instaurada na falta que produz demanda. Ela abre, para a linguagem e para o registro do intercâmbio, novas situações que revelam e despertam no brincante a necessidade de reatualizar vivências de crises anteriores sob condições de acompanhamento, expressadas em metáforas corporificadas. ${ }^{7}$

As metáforas corporificadas são elementos que apresento para analisar configurações no campo da educação e dos estudos sobre a diversidade. Elas dão vida e sentido ao que se traduz em formas e gestos culturalmente compartiIhados. Nosso corpo é atravessado e marcado pelos mais íntimos e sigilosos desejos de onde vazam conteúdos subjetivos inscritos, lidos e interpretados a partir do olhar do Outro, que dá sentido, compreende e interpreta como gesto portador de um dizer, estruturado nas relações vividas pelo sujeito com o ambiente que o cerca.

A leitura da máscara no corpo dos caboclos de lança revela seu saber brincante enquanto expressão de desejos e tensões. Não se trata apenas de um corpo orgânico de funções vitais, que possui encadeamento sensório-motor entre suas imagens, mas sim de um corpo sociocultural, um corpo investido pelo desejo do Outro mediatizando relações, e, dessa forma, um corpo simbólico visual-sonoro. Sendo assim, as metáforas corporificadas se processam de forma inter-relacional, incorporando informações culturais no corpo não como poder e verdade, mas percebendo que são registros e mudanças nas dinâmicas corporais, como nas danças dos brincantes em estudo, que fazem vir à tona memórias subterrâneas, fortalecidas nesse movimento dinâmico indisciplinar, fundante da comunicação. Para Foucault (1997, p. 41),

O corpo e tudo o que está em contato com ele é o lugar da proveniência: no corpo está o estigma dos acontecimentos passados; dele provêm também os desejos, as impotências e os erros (...) o corpo é uma massa que se desfaz sem cessar. Portanto, a genealo- 
gia está, como análise da proveniência, onde o corpo se entrelaça com a história.

Os aspectos apresentados com perfil histórico que não busca origem única e causal, mas que se baseia nas multiplicidades e nas lutas, apontam nesta pesquisa para elementos de estudos indisciplinares, ${ }^{8}$ segundo proposição de Greiner (2005), que revelam pontes invisíveis através das metáforas do pensamento tendo como táticas de persistência o movimento corporal, fundante da comunicação. Para a mesma autora, o fluxo de imagens na dramaturgia do corpo leva a processos de criação, reconstruindo no corpo que dança novos objetos e gestos, organizando uma diversidade de estados corporais sem os fragmentar, entendidos de modo inseparável e a partir de suas formas interna e externa de organização sensorial dispersiva no corpo. Sendo assim, considero que a sensorialidade no corpo dos caboclos de lança acontece como mecanismo para atrair ou afastar os indivíduos de seus interesses, pois a "dor e metamorfose têm sido os principais geradores de conceitos no mundo contemporâneo" (GREINER, 2005, p. 20).

No dispositivo imagético da máscara desses brincantes, vários elementos simbólicos imprimiram sua linguagem visual de corpo-máscara expressa em arte-movimento, e aponto os seguintes elementos de inspiração africana nela inscritos: 1. os caboclos de lança avançam no cortejo pelos canaviais da zona rural e pelas ruas e praças da zona urbana, criando seus jogos de guiadas, anunciando seu "grito organizado" e dispersivo com seu surrão, em que os badalos dos sinos que batem mais grosso nas extremidades se igualam aos que batem fino no centro, combinam com o som do terno, a partir das passadas também combinadas para as pancadas, e assim evocam suas tensões, depois expressas através das loas tiradas no improviso quando configuram suas caídas no apito; 2 . outros elementos são: o cone de cabeça (referência à cor do orixá de cabeça do brincante), o cravo (mistério sensível da mãe terra), a zarcão (fruta da qual o brincante tira a tinta vermelha para pintar o rosto, camuflando-se), a lança (metáfora para a determinação humana de revelar o que está escondido na natureza), os cordões (deslocamentos em filas e fileiras), o preparo do azougue (bebida em que, antes, se misturava azeite de dendê e que, agora, inclui cachaça, jurema), e do banho de ervas, para transe e proteção.

Toda essa cosmovisão corporificada em máscara insiste criativamente em permanecer na memória dos brincantes. Seja de forma defensiva, ofensiva ou jocosa, as ideias são geradas para explorar os mistérios da vida como metáforas corporificadas, invisíveis aos olhos daqueles que não querem ver ou que, de 
maneira discriminatória, sem considerar a diversidade humana, ainda rejeitam o que está fora de um padrão dominante na sociedade.

\section{CONSIDERAÇÕES FINAIS}

O cotidiano dos brincantes mantém estável a estrutura de seu sistema simbólico de saber, nas dimensões visível e invisível; porém, em sua ação dramática seu sistema simbólico de saber institui mudanças descontínuas que, ampliadas, originam a emergência de uma estrutura diferente, um novo padrão organizativo, tais como as mudanças associadas à transição das etapas do ciclo vital, que se configuram na competição de guerra, no passado dos brincantes, para sua competição estética, na atualidade. Essa guerra bonita transformada no tempo das redes sociais apontou configurações como suas caídas, seus cordões, sua forma de organizar seus objetos no corpo-máscara.

$\mathrm{O}$ ato de atuar atualizado no corpo que contém a semente da criatividade é o que enriquece o axé no brincante, permitindo-lhe retornar todos os anos ao convívio dessa manifestação cultural. Sendo assim, os africanos trouxeram para o carnaval suas tradições, seus festivais com cores... vestidos à moda de egungun (ancestrais que já morreram) configurados na memória através das sátiras que vão dando as dicas e reconhece todas as contribuições de homens e mulheres na sociedade, que depois são homenageados através de representações nas máscaras. Dar corpo a uma ideia colocando-a em movimento é o que dá maior ligação da arte com a vida. O propósito da arte em movimento, em ação, é criar o axé.

Para concluir este estudo reporto-me às ideias de Babatunde Lawa (2011), que aponta o mundo como o recado; o céu é a casa, e os homens entram nesse mundo através das máscaras. Ela é um meio. O mascarado é o triunfo do espírito humano, conceito que faz da vida uma performatividade. Sendo assim, os brincantes vivem fazendo apresentação performativa.

\section{REFERÊNCIAS BIBLIOGRÁFICAS}

ANDRADE, Mário de. Danças dramáticas do Brasil. (Org. Oneida Alvarenga), 2. edição. Belo Horizonte: Itatiaia/Fundação Nacional Pró-Memória, 1982.

BAKHTIN, Mikhail. A cultura popular na Idade Média e no Renascimento: o contexto de François Rebelais. Tradução Yara Frateschi Vieira. São Paulo: Hucitec, 2008.

BAUDRILLARD, Jean. A arte da desaparição. Tradução de Anamaria Skinner. Rio de Janeiro: Ed. UFRJ, 1997.

BENJAMIN, Roberto Emerson Câmara. Folguedos e danças de Pernambuco. 2. ed. Recife: PCR, 1989. 
BHABHA, Homi K. O local da cultura. Tradução De Myrian Ávila, Eliana Lourenço de Lima Reis, Glaucia Renata Gonçalves. Belo Horizonte: UFMG, 1998.

CARNEIRO, Edison. A sabedoria popular. 3. ed. São Paulo: Martins Fontes, 2008.

CERTEAU, Michel de. A invenção do cotidiano: 1. Artes de fazer. Tradução Ephraim Ferreira Alves. 4. ed. Petrópolis: Vozes, 1994.

DIAS, Lucy; GAMBINI, Roberto. Outros 500: uma conversa sobre a alma brasileira. São Paulo: Senac-São Paulo, 1999.

FOUCAULT, Michel. A arqueologia do saber. 5. ed. Rio de Janeiro: Forense Universitária, 1997.

FREITAS, Joseania Miranda et al. Obras-Primas do Patrimônio Oral e Imaterial da Humanidade: o Carnaval de Barranquilla e o Pelenque de San Basílio (Colômbia) e o Samba de Roda do Recôncavo Baiano (Brasil). Revista Brasileira do Caribe: Revista do Centro de Estudos do Caribe no Brasil/UFG, v.7, Goiânia, jan.-jul., 2007.

GEERTZ, Clifford. A interpretação das culturas. 1. ed., 13 reimpr. Rio de Janeiro: LTC, 2008.

GREINER, Christine. O corpo: pistas para estudos indisciplinares. São Paulo: Annablume, 2005.

GUERRA-PEIXE. Maracatus do Recife. 2. ed. Recife: Prefeitura da Cidade do Recife/Irmãos Vitale, 1980.

HALL, Stuart. Da diáspora: identidades e mediações culturais. Tradução Adelaine La Guardiã Resende. Belo Horizonte: UFMG; Brasília: Representação da Unesco no Brasil, 2003.

LAKOFF, George; JOHNSON, Mark. Metáforas da vida cotidiana. Tradução Mara Sofia Zanoto. Campinas: Educ, 2002.

LAWA, Babatunde. Sustaining the oneness in their twoness: poetics of twin figures (Ere İbeji) among the Yoruba. In: PEEK, Philip (ed.). Twins in african and diaspora cultures: double trouble, twice blessed. Bloomington and Indianapolis: Indiana University Press, 2011, 81-98.

MAUSS, Marcel. Sociologia e antropologia. Tradução Paulo Neves. São Paulo: Cosac Naify, 2003.

MENEZES, Lia. As yalorixás do Recife. Recife: Funcultura, 2005.

OLIVEIRA, Eduardo David. Cosmovisão africana no Brasil: elementos para uma filosofia afrodescendente. Fortaleza: LCD, 2003.

PEIRCE, Charles S.. Semiótica. Tradução José Teixeira Coelho Neto. 4. ed. São Paulo: Perspectiva, 2008.

POLLAK, Michael. Memória, esquecimento e silêncio. Estudos Históricos. Rio de Janeiro, v.2, n. 3, 1989.

SCC-MINC. Ação Griô no âmbito do Ministério da Cultura através da Secretaria de Cidadania Cultural (SCC-MinC-Ação Griô, 2010). Disponível em: http:// 
www.cultura.gov.br/culturaviva/category/cultura-e-cidadania/acao-grio/ Acessado em: 20/10/2010

SIMONDON, G. Du mode d'existence des objets techniques. Paris: Aubier-Montaigne, 1969.

\section{NOTAS}

1 Termo utilizado para designar genericamente os indivíduos que brincam e representam algum personagem nos folguedos (BENJAMIN, 1989). Eles transitam e interagem no mundo lúdico das manifestações culturais.

2 Griô é palavra abrasileirada que vem de griot, da língua francesa, que traduz Dieli (Jéli ou Djeli), cujo significado é o sangue que circula, na língua bamanan, do território do antigo império Mali, hoje dividido entre vários países do noroeste da África. Trata-se de caminhante, cantador(a), poeta popular, contador(a) de histórias, comunicador(a), mediador(a) político(a) da comunidade. Ele(a) é o sangue que faz circularem os saberes e histórias, mitos, lutas e glórias de seu povo, dando vida à rede de transmissão oral de sua região e seu país, como todo(a) cidadão(ã) que se reconheça e/ou seja reconhecido(a) por sua própria comunidade como: mestre das artes, da cura e dos ofícios tradicionais, líder religioso(a), brincante, tocador(a) de instrumentos tradicionais, que, através de pedagogia que valoriza o poder da palavra, da oralidade, da vivência e da corporeidade, se torna a biblioteca itinerante e a memória viva de seu povo. "A palavra é sagrada e, portanto, valorizada num processo ancestral como fio condutor entre as gerações e culturas" (SCC-MINC, 2010).

3 "Estão inclusos aqueles em que a musicalidade, os instrumentos musicais, as danças, a indumentária, as máscaras, as alegorias... são de inspiração africana" (FREITAS, 2007, p. 112).

4 Cantos que retratam o momento dos brincantes, tirados muitas vezes no improviso durante a brincadeira e quem o faz é o mestre de cabocaria do maracatu rural de Pernambuco, Brasil.

$5 \mathrm{~A}$ artificialidade essencial de um objeto ocorre porque o homem precisa interferir para manter o objeto existindo, protegendo-o contra o mundo natural e dando a ele uma forma separada de existência (SIMONDON, 1969, p. 46-7)

60 "baque solto" refere-se à batida solta das baquetas no tarol. Diferencia-se do maracatu nação ou de baque virado por suas performances e características musicais próprias, com orquestra formada por zabumba, surdo, tarol, cuíca, gonguê, ganzá, sendo já ampliada nos maracatus mais modernos com trompete, clarinete e trombone. $\mathrm{O}$ baque solto é imbuído de forte essência e mistério refletidos no sincretismo de seus personagens. Ele retrata a mensagem, o recado dos antepassados. Eram conhecidos no passado como "troças", tudo era troça. (GUERRA-PEIXE, 1980). 
7 As "metáforas corporificadas" são "dinâmicas corporais". Informações organizadas no corpo com simbioses de sínteses mutáveis reafirmadas e não afirmadas conectando memórias, ora no exercício da dominação cultural, ora da natureza do ser (biológico). Informação aberta inserida em uma visão de mundo como forma de conhecimento. Metáforas associadas a sensações corporificando o significado de ampliação da força vital e da ocupação do território (LAKOFF \& JOHNSON, 2002). São saberes brincantes.

8 É a desestabilização de objetos de estudos para além dos guetos teóricos, assim como a facilidade de suas respectivas teorias no mundo contemporâneo num campo bem pulverizado, em que ao corpo, o tempo inteiro, lhe é modificado e lançado em projeções futuras (GREINER, 2005).

José Antonio Carneiro Leão é mestre em gestão de políticas públicas, doutor em educação pela Universidade Federal da Bahia e professor efetivo do Departamento de Educação da Universidade do Estado da Bahia. e-mail: jleao@uneb. $\mathrm{br}$

Recebido em: 07/09/2012

Aceito em: 21/10/2012 